\title{
Økonomiske sanktioner som politisk værktøj
}

\section{Af John J. Forrer}

Økonomiske sanktioner er blevet et af den amerikanske regerings foretrukne politiske værktøjer. Men brugen af sanktioner og de dermed forbundne faldgruber er ofte blevet misforstået. Der er brug for en bedre forståelse af den rolle, sanktionerne kan eller ikke kan spille $i$ at fremme politiske mål, og den virkning, sanktionerne har på den private sektor, som bærer mange af omkostningerne af de pålagte økonomiske sanktioner.

$\varnothing$ konomiske sanktioner har vist sig at være et vigtigt udenrigspolitisk værktøj for Trump-administrationen. I løbet af mindre end et år har den skærpet eksisterende økonomiske sanktioner som svar på tvister med Nordkorea, Rusland, Cuba, Iran og Venezuela. I slutningen af 2017 indførte USA's udenrigsministerium sanktioner mod Myanmar på grund af dets behandling af Rohingya-befolkningen.

En særlig strategi brugt til at intensivere effekten af økonomiske sank- tioner mod Nordkorea og Rusland omtales som 'sekundære sanktioner'. Denne type sanktioner vedtages i tillæg til 'de primære sanktioner', der allerede er påført et land, organisation eller individ, og den har helt særlige karakteristika.

Globaliseringen har mindsket mange staters sårbarhed over for traditionelle økonomiske sanktioner, og det udgør en alvorlig udfordring med hensyn til at udforme og iværksætte $\varnothing$ konomiske sanktioner, der resulterer i økonomisk tab for målgrupperne i det sanktionsramte land.

At gribe til sekundære sanktioner for at øge effektiviteten af primære sanktioner kan være en måde at imødegå mindre end forventede konsekvenser af økonomiske sanktioner. Samtidig kan sekundære sanktioner være kontroversielle og deres effektivitet højst diskutabel. Før man gør brug af sekundære sanktioner, er det vigtigt, at man til fulde forstår de fordele og ulemper, der er forbundet med

John J. Forrer er direktør for Institute for Corporate Responsibility (ICR) og research professor ved School of Business and Associate Faculty, School of Public Policy and Public Administration, George Washington University. 
at bruge dem som udenrigspolitisk værktøj.

\section{Sekundære sanktioner}

Udtrykket 'sekundære sanktioner' er i sig selv forvirren-

de. Det antyder, at der findes en særlig slags økonomiske sanktioner, som kan lægges oven i de oprindelige 'primære sanktioner'; men sekundære sanktioner involverer mere end at påføre det sanktionsramte land yderligere økonomiske sanktioner.

Der er adskillige måder, hvorpå et land kan forsøge at intensivere sanktionernes virkning, efter at de er blevet sat i værk, herunder brugen af sekundære sanktioner.

\section{1) Udvid rækkevidden af mål: Effek-} ten af økonomiske sanktioner kan intensiveres ved at $ø$ ge deres rækkevidde: Forbyde import eller eksport af yderligere produkter; udvide listen af individer med indrejseforbud eller indefryse yderligere værdier.

Præsident Barack Obama underskrev i $2015 \mathrm{fx}$ et præsidentielt dekret, der erklærede Venezuela en trussel mod USA's nationale sikkerhed. Syv embedsmænd fra Venezuela blev udpeget og pålagt sanktioner for at have overtrådt venezuelanske menneskerettigheder. Præsident Obama sagde: "Vi er dybt foruroligede over den venezuelanske regerings bestræbelser på at optrappe truslerne over for deres politiske modstandere." I 2017 pålagde Trump-regeringen Venezuela yderligere økonomiske sanktioner, der begrænser den venezuelanske regerings salg af obligationer på det amerikan- ske marked. De nye sanktioner er en beskeden udvidelse, idet de indeholder adskillige dispensationer vedrørende oliesektoren.

At udvide rækkevidden af økonomiske sanktioner giver fleksible muligheder for at skrue op og ned for virkningerne af de økonomiske sanktioner som reaktion på forandrede omstændigheder i det berørte land og/ eller på USA's forventninger til sanktionernes virkning.

2) Udvid multilateral deltagelse: Det land, der i første omgang har pålagt de økonomiske sanktioner, kan anmode ligesindede lande om at deltage i sanktionerne mod det berørte regime. Indsatsen kan ske via udenrigsdiplomati eller gennem FN.

Fx har FN pålagt Nordkorea sanktioner ved ni forskellige lejligheder, begyndende i 2006. Men selvom FN's aktioner har udvidet rækkevidden af sanktioner, kan vedtagelsen af en FN-resolution ikke garantere deltagelse af alle nationer. For eksempel har Nordkorea mange lukrative forbindelser til afrikanske stater. Disse forbindelser blev dannet i 1960'erne, da Nordkorea støttede afrikanske løsrivelseskampe fra kolonimagterne, og siden har de udviklet sig til kommercielle forbindelser, hvor Nordkorea sælger militært udstyr eller sender arbejdere til afrikanske handelspartnere. 
Mens nogle af de afrikanske nationer synes at have indvilliget $i$ at deltage i FN-sanktionerne, er mange af de finansielle bånd intakte og har vist sig at være svære for det internationale samfund at kontrollere. Trumpadministrationen har lagt yderligere diplomatisk pres på bl.a. afrikanske stater for at fastholde FN's sanktioner. De seneste ophævelser af USA's økonomiske sanktioner over for Sudan er blevet kædet sammen med landets tilsagn om at kappe båndene til Nordkorea.

\section{3) Pålæggelse af ekstraterritoriale} $ø$ konomiske sanktioner: Det sanktionspålæggende land kan udvide sin økonomiske sanktionspolitik til udenlandsk placerede firmaer uden for sin jurisdiktion. Et velkendt eksempel er Helms-Burton Act, som præsident Bill Clinton ophøjede til lov i marts 1996 under navnet Den Cubanske Frihedsog Demokratiske Solidaritetslov. Loven strammede konditionerne for den eksisterende embargo mod Cuba. Den foreskrev straffe over for udenlandsk ejede (ikke amerikanske) firmaer, der var engageret $i$ 'uberettiget handel med ejendom konfiskeret af Castro regeringen' gennem handel med og investering i Cuba. Helms-Burton Act krævede, at amerikanske multinationale selskaber skulle sørge for, at deres datterselskaber i udlandet overholdt sanktionerne. Loven udløste protester fra lande, som anså sanktionerne for ulovlige. Lande hvor de fremmede datterselskaber var placerede.

4) Pålæggelse af sekundære sanktioner: Det sanktionspålæggende land kan forbyde udenlandske selskaber og individers kommercielle transaktioner med amerikanske statsborgere og firmaer for at forhindre deres økonomiske samarbejde med det land, der er ramt af 'primære' økonomiske sanktioner. Et nutidigt eksempel er de sekundære sanktioner, som USA har pålagt kinesiske firmaer og personer, der har finansielle transaktioner med Nordkorea. Den 19. juni 2017 pålagde USA en kinesisk bank, et kinesisk firma og to kinesiske borgere sanktioner. Banken må ikke handle med amerikansk baserede firmaer; Dalian Global må ikke foretage økonomiske transaktioner med amerikanske firmaer og borgere; og for Wei og Ris vedkommende indefrøs USA deres værdier og forbød dem at handle med amerikansk baserede selskaber og individer.

\section{Ekstraterritoriale sanktioner}

Forskere og praktikere sætter ofte lighedstegn mellem ekstraterritoriale sanktioner og sekundære sanktioner, men der er en betydelig forskel. Ekstraterritoriale sanktioner søger at tvinge selskaber placeret uden for det sanktionspålæggende lands grænser til at overholde de restriktioner, som sanktionerne indebærer. Sådanne foranstaltninger er ikke ualmindelige og var inkluderet i de sanktioner, som USA pålagde Cuba, Nordkorea, Kina og Vietnam i årene under den kolde krig.

Under præsident Ronald Reagan blev brugen af ekstraterritoriale sanktioner kontroversielt, da de ramte europæiske allierede, der var modstandere af USA's protester mod 
en naturgasledning. I 1982 fastlagde Reagan ekstraterritoriale sanktioner, der forbød udenlandske datterselskaber af amerikanske selskaber at sælge dele og tjenesteydelser til bygningen af en rørledning, der forbandt Sovjetunionen med vesteuropæiske kunder. Nogle europæiske lande protesterede mod disse tiltag og anførte, at de var ulovlige ifølge international lov, fordi de var uretmæssigt 'ekstraterritoriale' Den amerikanske regering skiftede til sidst kurs og ophørte med at pålægge amerikanske firmaers datterselskaber disse forbud.

Ekstraterritoriale sanktioner har også udløst bekymring med hensyn til overtrædelse af WTO's bestemmelser. I 1996 iværksatte Den Europæiske Union en WTO-procedure mod USA angående ekstraterritoriale aspekter i Helms-Burton loven. Denne lov fik EU, Canada og andre til at vedtage såkaldte blokerende vedtægter, som forbød selskaber inden for egen jurisdiktion at underordne sig det amerikanske sanktionsprogram mod Cuba.

WTO-uoverensstemmelsen blev til dels løst af en aftale mellem Clinton-administrationen og EuropaKommissionen, i hvilken begge parter forpligtede sig til ikke at opsøge eller foreslå og til at modsætte sig "vedtagelse af nye økonomiske sanktioner baseret på udenrigspolitiske årsager, som er udformet med henblik på at få de andres økonomiske aktører til at opføre sig på samme måde, som der kræves af ens egne økonomiske aktører".

Alternativt forsøger sekundære sanktioner ikke at tvinge fremmede datterselskaber til at følge et sanktionspålæggende lands politik, men begrænser egne firmaer og/eller borgere adgang til at gøre forretninger med bestemte firmaer og individer, som nægter at følge USA's økonomiske sanktionspolitik.

At nægte udenlandsk baserede firmaer og individer adgang til indenrigshandel og finansielle markeder er klart inden for nationernes rettigheder. Sekundære sanktioner er en taktik til at lægge pres på andre lande, for at disse skal indordne sig det sanktionspålæggende land.

I september 2017 bekendtgjorde præsident Trump endnu en sekundær sanktion for at intensivere de økonomiske konsekvenser for Nordkorea. Ifølge dette dekret vil USA's finansministerium nægte alle firmaer eller individer, der gør forretninger med Nordkorea, adgang til amerikanske markeder. Trump erklærede, at dette tiltag ville tvinge andre nationer og udenlandske firmaer til at foretage et valg: "Handl med USA eller med Nordkoreas lovløse regime."

Ekstraterritoriale økonomiske sanktioner er også en taktik til at tvinge lande til at tilslutte sig det sanktionspålæggende lands politik og påtvinge firmaer i andre lande en bestemt adfærd over for det sanktionsramte land. Sekundære sanktioner vælger en anden tilgang: 
Undlader man at rette sig efter de $ø$ konomiske sanktioner, betyder det forbud mod at gøre forretninger med det sanktionspålæggende land.

Alle former for økonomiske sanktioner - unilaterale, multilaterale, ekstraterritoriale eller sekundære - er kun redskaber til at opnå politiske mål.

Dybest set skal sekundære sanktioner ses som en måde at forstærke og/ eller udvide multilaterale sanktioner. Yderst sjældent har unilaterale sanktioner held til at påføre det sanktionsramte land tilstrækkelige økonomiske tab. Ved at overtale andre nationer til at slutte op bag sanktioner forstærkes sanktionernes virkning og derved deres udsigt til at blive effektive. I det væsentlige vil sekundære sanktioner påføre andre lande omkostninger for ikke at give deres fulde eller delvise støtte til sanktionerne.

Sekundære sanktioner har imidlertid betydelige begrænsninger. At pålægge et par firmaer og/eller individer sekundære sanktioner vil sandsynligvis ikke skabe tilstrækkeligt $\varnothing$ konomisk pres til at overvinde et lands modvilje mod at deltage i $\varnothing$ konomiske sanktioner. Omvendt vil det at udvide de sekundære sanktioner til et punkt, hvor økonomiske tab bliver smertefulde, kunne udløse ægte bitterhed. Det kan gøre afvisning af at deltage i økonomiske sanktioner til en måde at demonstrere et lands suverænitet på og måske skabe problemer for det sanktionspålæggende land inden for andre områder af internationale relationer.

\section{Hvornår virker de?}

Alle former for økonomiske sanktioner - unilaterale, multilaterale, ekstraterritoriale eller sekundære - er kun redskaber til at opnå politiske mål. Der findes ikke nogen logisk sandsynlighed for succes, med mindre de økonomiske sanktioner er trimmet til at skabe det niveau af økonomisk smerte, som er nødvendigt for at fremtvinge forandring i det sanktionsramte lands politik.

Akademikere og praktikere er dybt uenige om effektiviteten af sekundære sanktioner. Den overvejende holdning blandt forskere har almindeligvis været, at sekundære sanktioner ikke er et effektivt politisk værktøj. Argumenter og resultater til støtte for denne konklusion svarer til beviserne for effekten af unilaterale økonomiske sanktioner.

- Økonomiske tab fra sekundære sanktioner er sjældent store nok til at forandre et lands politik.

- Det ramte lands regering/regime bruger tit sanktionerne til at konsolidere sin politiske magt ved at dæmonisere det sanktionspålæggende land og til at mane til national stolthed.

- Sanktioner er rettet mod den politik, som det ramte land ikke under nogen omstændigheder er tilbøjelig til at ophæve - bortset fra ved et regimeskift.

- Sanktionerne har negative konsekvenser for individer og firmaer og giver ingen udenrigspolitiske fordele.

- De er vanskelige at gennemtvinge og forårsager således $ø$ konomiske lidel- 
ser - ofte for en uskyldig befolkning

- med ringe udsigter til succes.

Mange forskere mener, at sekundære sanktioner har alle de økonomiske sanktioners værste egenskaber plus den mulige ubehagelige bivirkning at starte nye konflikter med allierede og modstandere, som protesterer mod restriktioner og økonomiske trængsler, der påføres deres egne industrier og borgere. Enkelte er mere positive over udsigterne til, at sekundære sanktioner kan bruges effektivt, samtidig med at de erkender muligheden for at forværre forholdet til deres allierede.

På trods af den begrænsede akademiske støtte til sekundære sankti- oner fortsætter embedsmænd med at anse dem for levedygtige - og undertiden effektive - udenrigspolitiske redskaber.

Et godt eksempel er de krav, som præsident Obama, udenrigsminister Hillary Clinton og adskillige udenrigspolitiske eksperter stillede i forbindelse med Irans accept af at forhandle begrænsninger i dets atomberigelsesprogram.

I 2014 indvilligede præsident Hassan Rouhani i at føre internationale forhandlinger med det formål at begrænse og tillade inspektion af det iranske kernekraftprogram til gengæld for, at USA's og FN’s økonomiske sanktioner blev lettet og i sidste

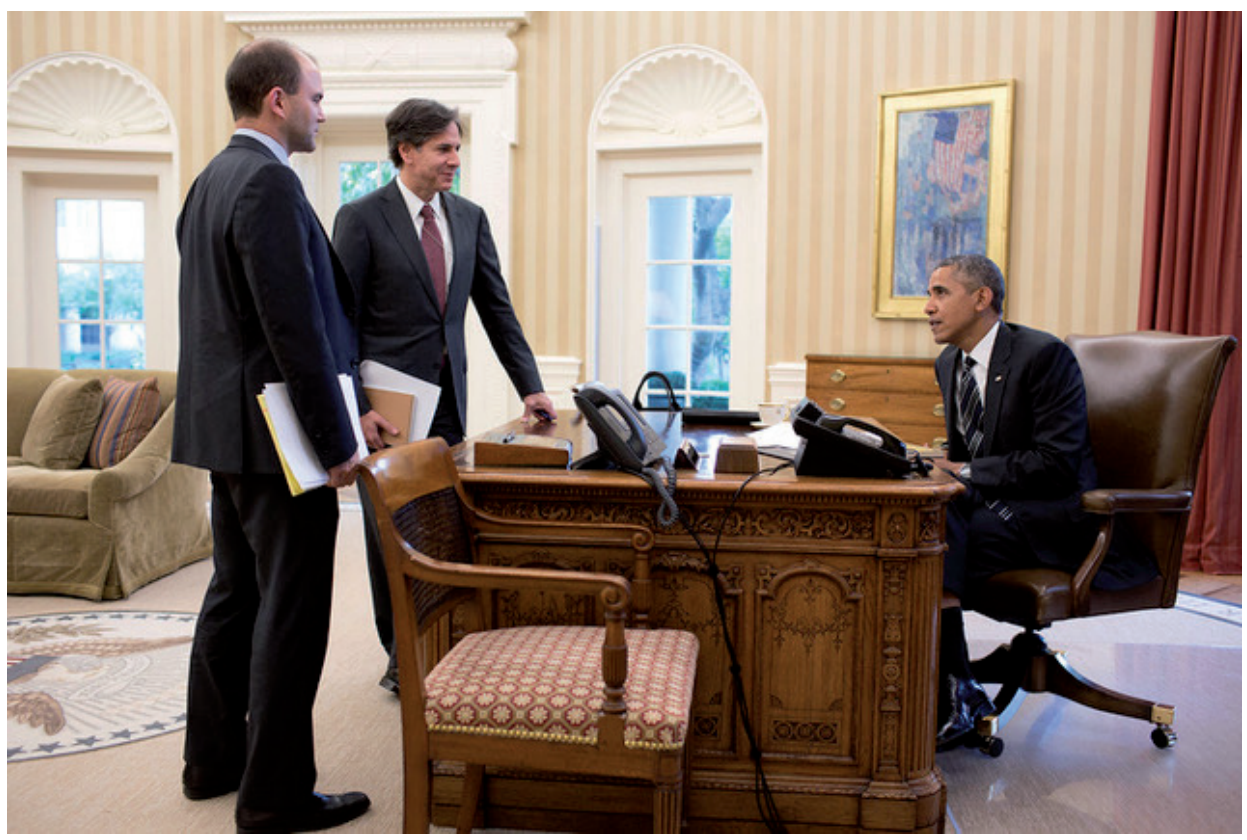

FOTO : Officielt foto fra Det Hvide Hus af Pete Souza via Wikimedia Commons

Præsident Barack Obama taler med Ben Rhodes, vice-national sikkerhedsrådgiver for strategisk kommunikation og vice-national Tony Blinken forud for en telefonsamtale med Irans præsident, Hassan Rouhani, i det ovale værelse, 27. september 2013 
instans ophævet. Forhandlingerne kulminerede i Joint Comprehensive Plan of Action (JCPOA) underskrevet af Iran, Kina, Frankrig, Rusland, Storbritannien, USA, Tyskland og Den Europæiske Union i juli 2015.

Hvilken rolle spillede sekundære sanktioner i dette diplomatiske gennembrud? Ser man på analyser og vurderinger af de betingelser og begivenhederne, der førte til overenskomsten, så medvirkede en aggressiv amerikansk diplomatisk offensiv til at sikre og gennemføre sekundære sanktioner, der ramte banker og andre selskaber, som gjorde forretninger med Iran. Disse sekundære sanktioner blev anset for at være nøglefaktoren, der overbeviste Iran om at forhandle en aftale på plads, der begrænsede dets kerneprogram, herunder international inspektion; sanktionerne var mest konsekvente fra 2010 til 2014.

Et betydeligt antal forretninger mellem Iran og andre lande blev bremset på grund af de amerikanske sanktioner mod stadig bredere kategorier af kommercielle transaktioner. Efterhånden som USA gradvist udvidede disse kategorier både gennem lovgivning og præsidentielle dekreter, "indskrænkede udenlandske selskaber og regeringer deres investeringer i Irans energisektor, standsede finansielle transaktioner med udpegede iranske banker og reducerede til sidst olieindkøbene fra Iran og tilbageholdt iranske indeståender i deres egne banker. Disse sekundære aktioner var virkningsfulde ikke blot på grund af truslen om, at udenlandske selskaber, der under dække gjorde forret- ninger med Iran, ville blive afskåret fra det amerikanske marked, men også på grund af accepten fra udenlandske regeringer, der ikke beskyttede deres egne firmaer" (David Mortlock, What Does the President's Decision on Iran Mean for Iran Sanctions? Not Much, Yet. Washington, DC: Atlantic Council, 2017).

Ligesom med alle økonomiske sanktioner betaler firmaer og individer en pris, når sekundære sanktioner indføres. Når sekundære sanktioner skønnes effektive, bliver de kommercielle tab hos firmaer og individer i både det sanktionspålæggende og de ramte lande anset for at være en $n \varnothing d-$ vendig del af omkostningerne for at nå det udenrigspolitiske mål. Desuden anses firmaer og individer, der gør forretninger med det ramte land, at have en uretmæssig fortjeneste - i det mindste fra det sanktionspålæggende lands perspektiv.

Når virkningen af sekundære sanktioner er usikker, skabes formålsløse økonomiske trængsler - ofte for uskyldige. Det afbryder forretningsforbindelser, der kan være vanskelige at genetablere, selv efter de økonomiske sanktioner er ophævet. Sekundære sanktioner bør aldrig benyttes som bare et redskab for at give udseende af at tage fornuftige forholdsregler mod en allieret eller modstander.

For eksempel har Trump-administrationen indført sekundære sanktioner som en diplomatisk pisk for at fremme kinesisk gennemtvingelse af $\varnothing$ konomiske sanktioner vedtaget af FN. Men en nylig rapport fandt, at niogfyrre nationer har gjort forretninger 
med og investeringer i Nordkorea og dermed overtrådt FN's sikkerhedsråds sanktioner.

I betragtning af den slappe håndhævelse af de primære sanktioner over for Nordkorea vil virkningen af de sekundære sanktioner sandsynligvis blive meget begrænset. At udvide antallet af sekundære sanktioner mod Kina til et niveau, hvor virkningen vil kunne føles af Nordkorea, kan også overstige Kinas tolerance med hensyn til indblanding $\mathrm{i}$ landets egen $ø$ konomi - udfordre dets suverænitet og risikere at skabe nye konflikter med Kina.

Trods den overvældende forskning, der finder, at sekundære sanktioner i det store og hele er ineffektive, ser de ud til at forblive et populært udenrigspolitisk værktøj. Regeringer, der tager sekundære sanktioner i brug, har en egeninteresse i at påberåbe sig deres

\section{Strategisk brug}

Forståelsen af forskellene mellem multilaterale, ekstraterritoriale og sekundære sanktioner er yderst vigtig for at udforme og iværksætte veltrimmede $\varnothing$ konomiske sanktioner. Hver og et af disse midler har vigtige implikationer for den tilgang, man bruger for at involvere andre lande og for at opnå støtte i det sanktionspålæggende land.

Den mest effektive tilgang vil afhænge af det enkelte lands forbindelse med det sanktionsramte land, dets interesse i at opnå det mål, der er forbundet med sanktionerne, og dets evne til at gøre gengæld mod det ramte land. Effektiviteten af sekundære økonomiske sanktioner skal ikke bedømmes anderledes end andre former for sanktioner. De kan være effektive, når de er udformet til at opnå de tilsigtede $ø$ konomiske konsekvenser under hensyntagen til det sanktionsramte lands sårbarhed.

Det sanktionspålæggende land kan vælge sekundære sanktioner af praktiske årsager. Det kan have udtømt alle sine muligheder for at succes - lige som ramte lande benægter deres betydning - og dermed forplumrer vurderingen af deres sande virkning.

Desuden er sekundære sanktioner en meget synlig måde at demonstrere en genopvakt forpligtelse til at nå det sanktionspålæggende lands udenrigspolitiske mål. Stridsspørgsmålet om virkningen af sekundære sanktioner bliver næppe endeligt løst, og værdien af dem vil blive bedømt fra sag til sag.

Regeringer, der tager sekundære sanktioner i brug, har en egeninteresse i at påberåbe sig ter deres betydning - og dermed forplumrer vurderingen af deres sande virkning. 
sanktioner og derved undgå økonomiske tab for dets egen økonomi, der ville forekomme ved at gennemføre $ø$ konomiske sanktioner.

Men den virkelige risiko forbundet med sekundære sanktioner kan imidlertid opveje deres potentielle fordel. I modsætning til traditionelle økonomiske sanktioner medfører sekundære sanktioner faren for gengældelse fra det land eller lande, hvor de anvendes. Fx har de sekundære sanktioner, som USA har pålagt kinesiske firmaer

\section{Tilhængere af økonomiske sanktioner} må forventes at stole på retfærdigheden i deres visioner om en forandring i det sanktionsramte lands politik, men det er urimeligt at forvente, at andre lande automatisk vil støtte deres forhåbninger.

og individer, til opgave at begrænse kommercielle transaktioner mellem Kina og Nordkorea for yderligere at svække den nordkoreanske økonomi. Men mon ikke Kina kan finde en måde at hævne sig på USA for de sanktioner, der er pålagt Kinas egne firmaer og borgere?

I praksis er forskellen mellem forskellige sanktionsmodeller ikke tydeligt afgrænset. For eksempel tillader amerikanske love om $ø$ konomiske sanktioner typisk en bred vifte af magtmidler. Et sådant bredt mandat tillader USA at agere efter eget skøn ikke kun over for det sanktionsramte land, men også over for andre, og det giver USA det lovmæssige grundlag, det behøver, for efter eget skøn at gennemføre sekundære sanktioner mod firmaer og individer.
Strategisk brug af sekundære sanktioner udgør et paradoks. Brugt i begrænset omfang - der kun berører nogle få firmaer og/eller individer og som reaktion på begivenhedernes udvikling - er udsigterne til, at de vil spille en væsentlig rolle med hensyn til at påvirke et andet lands entusiasme for $ø$ konomiske sanktioner, begrænsede. Men fordi effekten er minimal, vil sekundære sanktioner næppe pådrage sig nogen gengældelse af betydning.

Omvendt vil større brug af sekundære sanktioner - der udvider de berørte firmaer og individers $\varnothing$ konomiske tab - medføre større risiko for gengældelse. Og hvis det land, der er ramt af sekundære sanktioner, i det store og hele er for svagt til at tage modforholdsregler, vil traditionelt diplomatisk pres - uden sekundære sanktioner - fra det sanktionspålæggende land være tilstrækkeligt.

Tilhængere af økonomiske sanktioner må forventes at stole på retfærdigheden i deres visioner om en forandring i det sanktionsramte lands politik, men det er urimeligt at forvente, at andre lande automatisk vil støtte deres forhåbninger. Under de rigtige omstændigheder vil sekundære sanktioner kunne være en effektiv måde at presse andre lande til at støtte $ø$ konomiske sanktioner, men sådanne omstændigheder er sjældne.

Uden tillid til deres effektivitet vil det at pålægge firmaer og individer bosiddende i andre lande - både allierede og modstandere - sekundære sanktioner sandsynligvis resultere i unødvendig lidelse for dem, der bor i 
såvel de sanktionsramte og de sanktionspålæggende lande som i de lande, der er mål for sanktionerne.

Erfaringen fra brugen af sekundære sanktioner til at intensivere økonomiske sanktioner mod Iran giver en nyttig rettesnor for nogle af de særlige vilkår, hvorunder sekundære sanktioner kunne være et nyttigt udenrigspolitisk værktøj. Og erfaringer fra sekundære sanktioner brugt over for foretagender og individer skitserer et særlig sæt af omstændigheder, under hvilke sekundære sanktioner kunne være nyttige:

- Det sanktionspålæggende land kontrollerer en vital og vigtig handelsvare, der ikke er tilgængelig andre steder i den globale økonomi.

- Den sanktionsramte enhed kan nægtes adgang til denne handelsvare med begrænset udsigt til at finde en erstatning.

- Afslag på adgang resulterer i øjeblikkelige og mærkbare økonomiske tab eller bestemte tab i nær fremtid.
- De resulterende økonomiske tab for den sanktionsramte enhed er betydelige og permanente.

- De berørte lande udgør en omfattende og multilateral styrke.

- Det internationale samfund anser det sanktionsramte lands omstridte politik for et alvorligt problem.

I Irans tilfælde gjorde USA's og EU's samlede og omfattende anstrengelser for at nægte banker, der gjorde forretninger med Iran, adgang til Vestens banksystem, at Iran dybest set blev nægtet adgang til den globale økonomi med ødelæggende konsekvenser for dets økonomi til følge.

Heldige udfald af sekundære sanktioner antyder nødvendigheden af et multilateralt sanktionssystem.

000 